$$
\text { IN.07 }
$$

\section{4}

Nexy

\section{Performance and Durability of High Temperature Foil Air Bearings for Oil-Free Turbomachinery}

C. DellaCorte

Glenn Research Center, Cleveland, Ohio

V. Lukaszewicz

Akima Corporation, Brook Park, Ohio

M.J. Valco and K.C. Radil

U.S. Army Research Laboratory, Glenn Research Center, Cleveland, Ohio

H. Heshmat

Mohawk Innovative Technology, Inc, Albany, New York
ARL-TR-2202

$\lg _{5} 20$ 
Since its founding, NASA has been dedicated to the advancement of aeronautics and space science. The NASA Scientific and Technical Information (STI) Program Office plays a key part in helping NASA maintain this important role.

The NASA STI Program Office is operated by Langley Research Center, the Lead Center for NASA's scientific and technical information. The NASA STI Program Office provides access to the NASA STI Database, the largest collection of aeronautical and space science STI in the world. The Program Office is also NASA's institutional mechanism for disseminating the results of its research and development activities. These results are published by NASA in the NASA STT Report Series, which includes the following report types:

- TECHNICAL PUBLICATION. Reports of completed research or a major significant phase of research that present the results of NASA programs and include extensive data or theoretical analysis. Includes compilations of significant scientific and technical data and information deemed to be of continuing reference value. NASA's counterpart of peerreviewed formal professional papers but has less stringent limitations on manuscript length and extent of graphic presentations.

- TECHNICAL MEMORANDUM. Scientific and technical findings that are preliminary or of specialized interest, e.g., quick release reports, working papers, and bibliographies that contain minimal annotation. Does not contain extensive analysis.

- CONTRACTOR REPORT. Scientific and technical findings by NASA-sponsored contractors and grantees.
- CONFERENCE PUBLICATION. Collected papers from scientific and technical conferences, symposia, seminars, or other meetings sponsored or cosponsored by NASA.

- SPECIAL PUBLICATION. Scientific, technical, or historical information from NASA programs, projects, and missions, often concerned with subjects having substantial public interest.

- TECHNICAL TRANSLATION. Englishlanguage translations of foreign scientific and technical material pertinent to NASA's mission.

Specialized services that complement the STI Program Office's diverse offerings include creating custom thesauri, building customized data bases, organizing and publishing research results ... even providing videos.

For more information about the NASA STI Program Office, see the following:

- Access the NASA STI Program Home Page at http://www.sti.nasa.gov

- E-mail your question via the Internet to help@sti.nasa.gov

- Fax your question to the NASA Access Help Desk at (301) 621-0134

- Telephone the NASA Access Help Desk at (301) 621-0390

- Write to: NASA Access Help Desk NASA Center for AeroSpace Information 7121 Standard Drive Hanover, MD 21076 
NASA/TM-2000-209187/REV1

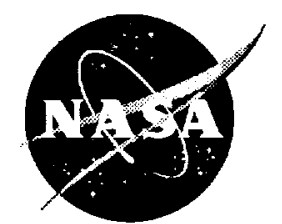

\section{Performance and Durability of High Temperature Foil Air Bearings for Oil-Free Turbomachinery}

C. DellaCorte

Glenn Research Center, Cleveland, Ohio

V. Lukaszewicz

Akima Corporation, Brook Park, Ohio

M.J. Valco and K.C. Radil

U.S. Army Research Laboratory, Glenn Research Center, Cleveland, Ohio

H. Heshmat

Mohawk Innovative Technology, Inc, Albany, New York

Prepared for the

Annual Meeting

sponsored by the Society of Tribologists and Lubrication Engineers

Nashville, Tennessee, May 7-11, 2000

National Aeronautics and

Space Administration

Glenn Research Center 
This report contains preliminary findings, subject to revision as analysis proceeds.

Available from

NASA Center for Aerospace Information 7121 Standard Drive

Hanover, MD 21076

Price Code: A03
National Technical Information Service 5285 Port Royal Road Springfield, VA 22100 Price Code: A03 


\title{
Performance and Durability of High Temperature Foil Air Bearings for Oil-free Turbomachinery
}

\author{
C. DellaCorte \\ National Aeronautics and Space Administration \\ Glenn Research Center \\ Cleveland, Ohio \\ V. Lukaszewicz \\ Akima Corporation \\ Brook Park, Ohio \\ M.J. Valco and K.C. Radil \\ U.S. Army Research Laboratory \\ Glenn Research Center \\ Cleveland, Ohio \\ H. Heshmat \\ Mohawk Innovative Technology, Inc. \\ Albany, New York
}

\section{Summary}

The performance and durability of advanced, high temperature foil air bearings are evaluated under a wide range ( 10 to $50 \mathrm{kPa}$ ) of loads at temperatures from 25 to $650^{\circ} \mathrm{C}$. The bearings are made from uncoated nickel based superalloy foils. The foil surface experiences sliding contact with the shaft during initial start/stop operation. To reduce friction and wear, the solid lubricant coating, PS304, is applied to the shaft by plasma spraying. PS304 is a $\mathrm{NiCr}$ based $\mathrm{Cr}_{2} \mathrm{O}_{3}$ coating with silver and barium fluoride/calcium fluoride solid lubricant additions.

The results show that the bearings provide lives well in excess of 30,000 cycles under all of the conditions tested. Several bearings exhibited lives in excess of 100,000 cycles. Wear is a linear function of the bearing load. The excellent performance measured in this study suggests that these bearings and the PS304 coating are well suited for advanced high temperature, oil-free turbomachinery applications.

\section{Introduction}

Foil air bearings have been used successfully in many aerospace applications such as air cycle machines, bleed air turbocompressors and turbo expanders (refs. 1 to 4). These applications are characterized by light loads, constant speeds and low to moderate temperatures. Previous efforts to extend the technology into high load, high temperature applications have failed due to inadequate load capacity, material capabilities or rotordynamic performance (refs. 5 and 6 ). However, recent advances in foil air bearing design have resulted in significant improvements in load capacity, damping and stiffness performance opening up new possibilities for their application in advanced oil-free turbomachinery (refs. 7 to 9$)$.

High temperature operation, however, continues to be a key obstacle. Foil air bearings float on a self-acting hydrodynamic air film during normal operation and hence do not experience sliding contact or wear. However, during start-up and shut down, prior to developing a gas film, sliding occurs and solid lubrication must be provided to reduce friction and wear. Previous efforts to lubricate foil bearings at high temperatures have been met with limited success. Bushan et al evaluated a number of foil and journal coatings which, in some cases, allowed operation 
to $650^{\circ} \mathrm{C}$ but life was limited (ref. 10). DellaCorte and Sliney evaluated a chrome carbide journal coating in partialarc bearing tests and found good performance but later difficulties were exhibited regarding coating repeatability and high processing costs (refs. 11 to 13). Due to these and other problems, foil air bearing use has been limited to operation with polymer foil coatings operating below about $300^{\circ} \mathrm{C}$.

Efforts to develop improved tribomaterials for foil bearing lubrication are underway at the authors' laboratories. A new chrome oxide based journal coating, designated PS300, was shown to provide good friction and wear properties in a partial-arc foil bearing at $500^{\circ} \mathrm{C}$ (ref. 14). At room temperature, however, high foil wear was observed unless a thin ceramic coating was applied to the foil. In addition, journal coating adhesion was poor especially during repeated thermal cycles. Subsequent research resulted in a modification to this coating, PS304, which exhibited excellent adhesion and substantially improved tribological performance in a partial-arc foil bearing (ref. 15). Under the conditions tested, wear at $25^{\circ} \mathrm{C}$ was acceptable yet significantly higher than at elevated temperatures.

The present study extends the partial-arc bearing tests of PS304 to advanced design full foil bearings. Particular emphasis is placed on bearing friction, wear and the effects of temperature and load on wear and performance. The sliding wear surfaces of full foil bearings are not accessible for conventional surface analyses (microscopy). Therefore, the reader is referred to previous work with these tribomaterials in partial arc bearings for detailed tribosurface characterization (refs. 14 and 15).

\title{
Apparatus, Materials and Procedures
}

\author{
Foil Bearings
}

The test foil bearings are nominally $35 \mathrm{~mm}$ in diameter, $25 \mathrm{~mm}$ long (or wide) and made up of several layers of nickel-based superalloy foils typically $0.13 \mathrm{~mm}$ thick. These foil layers consists of a smooth innermost or top foil backed by bump foils. The top foil supports the hydrodynamic gas film while the underlying foils provide an elastic and compliant support structure for the top foil. Figure 1 shows a cross-section schematic of a typical test bearing. In addition to their role in providing a compliant support, the underlying foils also provide coulomb damping to the bearings by allowing microsliding to occur between the bumps and adjacent surfaces. The resulting stiffness and damping characteristics as well as compliance to accommodate centrifugal and thermal distortions and misalignment are attractive features of foil bearings. Furthermore, judicious design selection of bump heights, pitch, foil thickness and the location(s) and mean(s) for foil layer attachment allow the tailoring of stiffness and damping performance for a given application (ref. 16).

\section{Test Journals}

The test journals shown in figure 2 are nominally $35 \mathrm{~mm}$ long and $35 \mathrm{~mm}$ in diameter and made from a nickelbased superalloy. The joumals have a series of twelve equally spaced, threaded holes in the front face to accommodate weights for in-place, high speed, dynamic balancing. The journals have a premachined undercut, $0.25 \mathrm{~mm}$ deep, to allow for the deposition of the solid lubricant test coating.

\section{PS304 Test Coating}

The foil bearings are lubricated during the sliding experienced at initial start-up and final shut-down by applying the solid lubricant, PS304, onto the journal surface. PS304 is a nickel-chrome bonded chrome oxide plasma sprayed composite coating with silver and barium-fluoride/calcium fluoride lubricant additives. The detailed composition is given in table I and a representative cross-section photomicrograph is shown in figure 3 . The nickelchrome acts as a binder while the chrome oxide functions as both a hardener and a high temperature lubricant (ref. 17). Silver is added as a thermochemically stable low temperature lubricant. The fluoride acts as a high 
temperature lubricant. As a journal coating, PS304 provided excellent lubrication performance to partial-arc (1/2 circumference) foil bearings at temperatures above $200^{\circ} \mathrm{C}$. Wear at room temperature was substantially higher (ref. 15). The purpose of the current effort is to further explore the performance of PS304 in lubricating full foil bearings from 25 to $650^{\circ} \mathrm{C}$ and measure the effects of load and temperature on wear.

\section{Test Apparatus/Procedure}

For these evaluations, start-stop operation of the test bearings is conducted using the test rig shown in figure 4 and fully described in reference 18 . This test rig uses an impulse turbine driven by compressed air to achieve test speeds up to $70,000 \mathrm{rpm}$. The rig spindle is supported by ceramic-hybrid ball bearings lubricated by oil jets and cooled by temperature controlled water. The start/stop test cycle lasts $20 \mathrm{sec}$ and is shown in figure 5 . The cycle begins by turning on the air supply to the turbine. The air pressure then builds until the torque provided by the turbine exceeds the static torque of the test bearing plus any torque contribution of the spindle bearings. Test bearing torque reaches a peak then sliding begins followed by a reduction in test bearing torque due to the formation of a lubricating air film. Above about $4,000 \mathrm{rpm}$ the air film is fully developed, no wear occurs, and the friction is reduced to its lowest value. During the on portion of the cycle the spindle reaches $40,000 \mathrm{rpm}$ at which point the turbine air supply is shut off allowing the spindle to coast to a stop. As the spindle slows, the test bearing torque gradually climbs as the gas film shear rate increases and at speeds below about $4000 \mathrm{rpm}$ sliding recommences on the bearing until the spindle comes to a complete stop. The test apparatus is fully instrumented and designed to operate unattended, $24 \mathrm{hr} /$ day allowing for convenient data collection.

The specimens are heated using quartz tube heating lamps located circumferentially around the bearing. Proximity thermocouples monitor the test temperature and are used for safety and control. Torque is monitored during the cycle by using a load cell to measure the force required to restrain the bearing from rotation as shown in figure 6 . A static load of $10.1 \mathrm{kPa}$ (1.5 psi) is applied to the bearing using a donut shaped dead weight housing inside which the bearing is mounted. For some tests, this load is augmented by dead weights hung from a cable beneath the test rig or through the use of an instrumented pneumatic actuator (fig. 6).

Specimen wear is measured by using micrometers to assess the minimum foil thickness (usually occurring in the heavily loaded zone at the top of the bearing) and the decrease in journal diameter. Past experience with foil bearings suggested that performance (load capacity) was degraded when $\sim 0.025 \mathrm{~mm}$ was worn from either the foil or journal surface (refs. 10 and 11). More recent evidence from advanced design bearings suggests that the bearings can continue to provide excellent performance well beyond this point. Therefore, testing of bearings in this program will continue until either the designated number of startstop cycles has been reached (typically 30,000 ) or the foil surface wears through to an underlying foil layer. 30,000 cycles represents twice the required cycles for many anticipated foil bearing applications such as turbochargers and turboalternators.

Due to high specimen costs and long test duration, repeat tests were generally not performed. To assess data scatter and repeatability, the performance measured here at selected test conditions (e.g. $10.1 \mathrm{kPa}$ load, to $538^{\circ} \mathrm{C}$ ) was compared to that collected during earlier work. Good agreement was observed and, therefore, repeat tests were not performed.

\section{Test Results}

The friction and wear data summary for the bearings tested is given in table II. The first group (of five bearings) shown in the table were tested at a constant $10.1 \mathrm{kPa}(1.5 \mathrm{psi})$ static load while the test temperature was varied from 25 to $650^{\circ} \mathrm{C}$. The tests were run until each bearing had successfully reached over 30,000 start/stop cycles. Start/stop bearing torque decreased sharply with temperature varying from $238 \mathrm{~N}-\mathrm{mm}$ at $25^{\circ} \mathrm{C}$ to $57 \mathrm{~N}-\mathrm{mm}$ at $650^{\circ} \mathrm{C}$. Foil wear ranged from 8 to $18 \mu \mathrm{m}$ and journal wear ranged from 5 to $20 \mu \mathrm{m}$. No obvious trends of wear with temperature were observed.

The second group (of three bearings) shown in table II were all tested at $538^{\circ} \mathrm{C}\left(1000^{\circ} \mathrm{F}\right)$ under test loads of $20.2,33.7$ and $53.9 \mathrm{kPa}$. By including the bearing in the first group which was also tested at $538^{\circ} \mathrm{C}\left(1000^{\circ} \mathrm{F}\right)$ at a $10.1 \mathrm{kPa}$ load, four tests at this test temperature were performed. Bearing wear, both journal and foil, are plotted in 
figures 7 and 8 and ranged from 15 to $69 \mu \mathrm{m}$. The figures show the linearity of the wear data with load as expected. Torque also increased with load but is not a simple linear relationship because four different bearings were tested and each has a slightly different preload level, which confounds the data comparison. This topic will be discussed in more detail later.

The third group (of four bearings) shown in table II were run under endurance tests to ascertain bearing life. The test at $25^{\circ} \mathrm{C}$ was discontinued after 48,372 cycles due to excessive top foil wear. The elevated temperature tests were discontinued without failure after 100,000 cycles, the prescribed test sequence limit. For all of these tests, a high static load $(33.7 \mathrm{kPa})$ was chosen to accelerate the wear process. Both torque and measured wear values corroborated the shorter tests conducted earlier.

\section{Discussion of Results}

\section{Bearing Torque and Friction}

The data given in table II clearly show that bearing torque increases with load and decreases with temperature. Bearing torque is the result of the combination of two factors. The first factor is the friction coefficient and the second factor is the contact stress between the journal coating and the foil. The contact stress arises from both external applied loads, such as dead weights, and the spring preloading of the foil against the shaft. All foil bearings are lightly spring preloaded to maintain shaft concentricity and avoid dynamic instability during start-up. Spring preload levels are typically 3.0 to $10.0 \mathrm{kPa}$ and therefore can be responsible for a significant proportion of the start-up torque of a bearing supporting a lightweight shaft. For current foil bearing supported turbomachinery, typical deadweight levels (or start up loads) range from 6.0 to $20.0 \mathrm{kPa}$.

For the bearing tests conducted here, the preload level at a particular test condition (i.e. temperature) is unknown. It can be estimated, however, in the following manner. The deadweight load can be varied resulting in corresponding changes to the measured bearing torque. By carefully conducting start/stop tests under various deadweight loads this relation between bearing friction (torque) and deadweight load can be measured. Data of this type is shown in figure 9 for a bearing tested at $25^{\circ} \mathrm{C}$. The data points can be fitted to a straight line whose slope is the sliding friction coefficient for the bearing/coating tribopair. For this bearing, the coefficient is 0.22 . This value is significantly lower than the apparent friction coefficient calculated from a single data point taken under low deadweight loading conditions. Table II gives apparent friction values at $25^{\circ} \mathrm{C}$, which range from 1.39 at $10.1 \mathrm{kPa}$ load to 0.53 at $33.7 \mathrm{kPa}$ load. The discrepancies between the calculated value $(0.22)$ and the apparent values are due to the sping preload contributions to the friction force. The spring preload contribution can be quite significant because it is a surface force acting over the entire shaft surface area ( $\Pi \times$ diameter $\times$ width).

A similar calculation of the friction coefficient can be made at each test condition (temperature). These calculations are plotted in figures 10 to 13 and tabulated in table III. As can be seen from this table, calculated friction coefficients range from 0.25 to 0.16 . Correlation coefficients for the straight-line fits are very near 1.0 lending further credibility to this method of friction coefficient calculation.

Upon closer examination of figure 9, one can see that the fitted friction line can be extrapolated to lower deadweight loads as if one were to hypothetically reduce gravity. If gravitational effects were eliminated the line intersects the ordinate at the friction level due only to the spring preload multiplied by the previously calculated friction coefficient. If this preload induced friction force is then divided by the friction coefficient, the spring preload force can be calculated.

Table III shows the preload values for a single bearing operated at 25 to $650^{\circ} \mathrm{C}$ after 30,000 start/stop cycles of operation at $537^{\circ} \mathrm{C}$ under a $10.1 \mathrm{kPa}$ load. The data, which is plotted in figure 14 , is well behaved and increases smoothly with test temperature above $204^{\circ} \mathrm{C}$. This change is understandable. The bearing has a spring preload against the shaft, which is similar to a light interference fit. Since all of the materials (the bearing, housing, joumal) have the same thermal expansion coefficient, as the temperature is increased the preload (interference) increases. From the data (table III and fig. 14) it appears that the preload pressure increases by a factor of two between 204 and $6500^{\circ} \mathrm{C}$.

The data obtained at $25^{\circ} \mathrm{C}$ does not fit this explanation. The preload pressure at $25^{\circ} \mathrm{C}$ is nearly double that at $650^{\circ} \mathrm{C}$. The reasons for this discrepancy are not exactly known but are likely due to the experimental lab set-up. For all of the tests above $25^{\circ} \mathrm{C}$, the test bearing is heated by the furnace, which maintains the desired ambient test temperature. For these cases, both the bearing and the journal are at nominally the same temperature. 
At $25^{\circ} \mathrm{C}$, however, the furnace is off and the bearing housing is at $25^{\circ} \mathrm{C}$ while frictional heat generated in the gas film quickly heats the shaft to over $100^{\circ} \mathrm{C}$. Because the thermal mass of the bearing housing is large, it remains at $25^{\circ} \mathrm{C}$. Therefore, the shaft grows by thermal expansion increasing the preload level. Since the built-in spring preload pressures are small compared to the pressures generated by shaft thermal expansion deflecting the (spring) bump foil layer small shaft temperature increases can have a dramatic effect on total preload pressure. This explains the high preload value calculated at $25^{\circ} \mathrm{C}$.

\section{Bearing Wear}

Foil bearings which are currently in production applications such as air cycle machines (ACM's) typically use thin soft polymer coated foils against hard coated shafts to reduce friction and wear. In these applications wear of the foil coatings are not well tolerated because during startup and shutdown, the same regions of the foil surface rub on the shaft causing localized coating wear. Once the solid lubricant coating on the foil is worn through to the metal substrate, friction increases, and galling and seizure can occur. In addition, since soft coatings are used, any contaminants in the system (e.g. dust, sand) can cause abrasion and accelerate wear.

For the bearings tested here a different approach has been employed. Relatively hard, thick solid lubricant composite coatings are applied to the journals which slide against uncoated metal foils during startup and shutdown. In essence, the entire top foil thickness is available as a sacrificial wear surface and the entire journal surface acts as a solid lubricant reservoir. No change in friction performance occurs as the coating/foil tribopair wears. Therefore, the friction (torque) and load capacity of the tested bearings do not change over the duration of the tests.

This approach to foil bearing lubrication appears to be successful as evidenced by bearing lives in excess of 100,000 cycles under high loads as shown in table II. Even after 100,000 cycles, the test bearing load capacity was not reduced. At room temperature, wear is much higher, resulting in bearing failure (wear through of the top foil) after 48,000 cycles. This result has been observed in earlier work using a partial arc bearing (ref. 15). Clearly the PS304 coating is much more abrasive at $25^{\circ} \mathrm{C}$ than at elevated temperatures. Fortunately, most turbomachinery operates at $25^{\circ} \mathrm{C}$ for only a small percentage of their duty cycles. Thus room temperature wear may be a secondary issue.

The linearity in the wear data shown in figures 7 and 8 suggest that the data obtained in this research can be used for design life guidance in future applications. The data show that over the wide range of static loads tested $(10$ to $+50 \mathrm{kPa}$ ), the wear increases only linearly. Further, the wear data can be used to accommodate bearing wear into the design preload to enhance dynamic stability of the rotor system even after long term use.

\section{Concluding Remarks}

This paper presents tribological performance and durability data for advanced foil air bearings operating between 25 and $650^{\circ} \mathrm{C}$. The data clearly show that these bearings perform well over a wide range of static loads and exhibit wear lives well in excess of what would be required for near or long term applications. The results also show that some bearing wear is acceptable and can be accommodated through proper bearing design. Based upon the results, these bearings and tribological coatings are well suited for advanced turbomachinery applications such as turbochargers, auxiliary power units, and gas turbine engines.

\section{References}

1. Agarwal, G.L.: "Foil Gas Bearings for Turbomachinery." Soc. Of Automotive Engineers, Paper Number 901236, 1990.

2. Saville, M.; Gu, A. and Capaldi, R.: "Liquid Hydrogen Turbopump Foil Bearing." AIAA-91-2108, Washington, DC, 1991. 
3. Heshmat, H. and Hermel, P.: "Compliant Foil Bearing Technology and Their Application to High Speed Turbomachinery." The $19^{\text {th }}$ Leeds-Lyon Symposium on Thin Film in Tribology - from Micro Meters to Nano Meters, Leeds, U.K., Sep. 1992, D. Dowson et al. (Editors), Elsevier Science Publishers B.V., (1993), pp. 559-575.

4. Heshmat, H.: "Role of Compliant Foil Bearings in Advancement and Development of High-Speed Turbomachinery." Presented at the Second ASME Pumping Machinery Symposium, Fluid Engineering Conference, June 20-24, 1993, Publication of ASME Pumping Machinery, Ed. By P. Cooper, FED-Vol. 154, (1993), pp. 359-377.

5. Surianu, F.J.; Dayton, R. and Woessner, F.: "'Test Experience with Turbine end Foil Bearing Equipped Gas Turbine Engines." ASMA Paper 93-GT-73, 1993.

6. Chen, S.H. and Arora, G.K.: "Development of a 1000F, 10,000 Start/Stop Cycles Foil Journal Bearing for a Gas Turbine Engine." AIAA Paper A87-23253, 1987.

7. Heshmat, H.: Advancements in the Performance of Aerodynamic Foil Journal Bearings: High Speed and Load Capability." ASME Tribology Conference, Paper No. 93-Trib-32, 1993.

8. Agarwal, G.L.: "Foil Air Bearings Cleared to Land." Mechanical Engineering, July 1998, pp. 78-80.

9. Heshmat, H. and Walton, J.: "High Temperature Damper Development," Final Report for 09/30/90 - 09/30/94, Aero Propulsion and Power Directorate, WLAFB, Ohio, Report No. WL-TR-94-2118, Oct. 1994.

10. Bushan, B. and Rusietto, D.: "Hydrodynamic Air Lubricated Compliant Surface Bearing for an Automotive Gas Turbine Engine-II: Materials and Coatings." NASA CR-135402, July 1978.

11. DellaCorte, C.: "Composition Optimization of Chromium Carbide Based Solid Lubricant Coatings for Foil Gas bearings at Temperatures to $650^{\circ} \mathrm{C}$." NASA CR-179649, July 1987.

12. DellaCorte, C. and Sliney, H.E.: "Composition Optimization of Self-Lubricating Chromium Carbide Based Comparative Coatings for Use to 760C." ASLE Transactions, Vol. 30, No. 1 pp. 77-83 (1987).

13. Sliney, H.E.: "Some Composite Bearing and Seal Materials for Gas Turbine Applications-A Review." J. of Eng. For Gas Turbines and Power, Transactions of ASME, Vol. 112, pp. 486-491, 1990.

14. DellaCorte, C.; Fellenstein, J.A. and Benoy, P.A.: "Evaluation of Advanced Solid Lubricant Coatings for Foil Air Bearings Operating at 25 and 500C." NASA TM-1998-206619, 1998.

15. DellaCorte, C.: "The Evaluation of a Modified Chrome Oxide Based High Temperature Solid Lubricant Coating for Foil Gas Bearings." NASA TM-1998-208660, 1998.

16. Heshmat, H.: "Analysis of Compliant Foil Bearings with Spatially Variable Stiffness." AIAA-91-2102-CP, Washington, DC, 1991.

17. DellaCorte, C. and Edmonds, B.J.: "Preliminary Evaluation of PS300: A New Self-Lubricating High Temperature Composite Coating for Use to 800C, "NASA TM-107056 (1995).

18. DellaCorte, D.: "A New Foil Air Bearing Test Rig for Use to 700C and 70,000 rpm." NASA TM-107405, 1997. 
TABLE II.-BEARING TRIBODATA SUMMARY

\begin{tabular}{|c|c|c|c|c|c|c|}
\hline $\begin{array}{c}\text { Test } \\
\text { temperature, } \\
{ }^{\circ} \mathrm{C}\end{array}$ & $\begin{array}{c}\text { Static load, } \\
\text { kPa, } \\
\text { (psi) }\end{array}$ & $\begin{array}{l}\text { Number } \\
\text { start/stop } \\
\text { cycles }\end{array}$ & $\begin{array}{l}\text { Start/stop } \\
\text { torque, } \\
\text { N.mm }\end{array}$ & $\begin{array}{l}\text { Apparent } \\
\text { friction } \\
\text { coefficent }\end{array}$ & $\begin{array}{c}\text { Foil wear, } \\
\mu \mathrm{m}\end{array}$ & $\begin{array}{c}\text { Diametral } \\
\text { journal wear, } \\
\mu \mathrm{m}\end{array}$ \\
\hline 25 & $10.1(1.5)$ & 33,129 & 238 & 1.39 & 10 & 20 \\
\hline 204 & $10.1(1.5)$ & 30,400 & 124 & 0.73 & 18 & 5.1 \\
\hline 427 & $10.1(1.5)$ & 32,500 & 104 & $0.6 I$ & 18 & 7.6 \\
\hline 538 & $10.1(1.5)$ & 32,375 & 58 & 0.34 & 18 & 15 \\
\hline 650 & $10.1(1.5)$ & 30,000 & 57 & 0.33 & 8 & 5.1 \\
\hline 538 & $20.2(3.0)$ & 30,258 & 156 & 0.45 & 25 & 28 \\
\hline 538 & $33.7(5.0)$ & 31,486 & 233 & 0.41 & 30 & 36 \\
\hline 538 & $53.9(8.0)$ & 30,000 & 264 & 0.29 & 38 & 69 \\
\hline 25 & $33.7(5.0)$ & ${ }^{6} 48,372$ & 303 & 0.53 & $100^{6}$ & 100 \\
\hline 178 & $33.7(5.0)$ & 100,000 & I6I & 0.28 & 25 & 50 \\
\hline 316 & $33.7(5.0)$ & 100,000 & 146 & 0.26 & 57 & 41 \\
\hline 650 & $33.7(5.0)$ & 100,000 & 90 & 0.16 & 10 & 25 \\
\hline
\end{tabular}

${ }^{3}$ Apparent friction coefficient is calculated without accounting for bearing preload force, i.e., $\mu$ is the measured friction force divided by the total dead weight load.

${ }^{b}$ Bearing test terminated due to high wear.

TABLE III.-CALCULATED FRICTION AND PRELOAD DATA [Bearing length; $2.7 \mathrm{~cm}$; diameter: $3.5 \mathrm{~cm}$.]

\begin{tabular}{|c|c|c|c|c|c|}
\hline $\begin{array}{c}\text { Temperature, } \\
{ }^{\circ} \mathrm{C}\end{array}$ & $\begin{array}{c}\text { Calculated } \\
\text { friction } \\
\text { coefficient }\end{array}$ & $\begin{array}{c}\text { Correlation } \\
\text { coefficient }\end{array}$ & $\begin{array}{c}\text { Friction force } \\
\text { at no load, } \\
\mathrm{N}\left(\mathrm{g}_{\text {force }}\right)\end{array}$ & $\begin{array}{c}\text { Preload force } \\
\text { at no load, } \\
\mathrm{N}\left(\mathrm{g}_{\text {force }}\right)\end{array}$ & $\begin{array}{c}\text { Preload } \\
\text { pressure, } \mathrm{kPa} \\
(\mathrm{psi})^{\mathrm{b}}\end{array}$ \\
\hline 25 & 0.22 & 0.98 & $4.7(475)$ & $21.2(2160)$ & $7.2(1.1)$ \\
\hline 204 & 0.25 & 0.98 & $1.7(173)$ & $6.8(692)$ & $2.3(0.34)$ \\
\hline 427 & 0.21 & 0.99 & $1.9(192)$ & $9.0(914)$ & $3.0(0.45)$ \\
\hline 537 & 0.19 & 0.99 & $2.2(225)$ & $1.2(1184)$ & $3.9(0.57)$ \\
\hline 650 & 0.16 & 0.99 & $2.2(222)$ & $1.4(1388)$ & $4.6(0.67)$ \\
\hline
\end{tabular}

"Friction coefficient measured at loads ranging from $10.2 \mathrm{kPa}(1.5 \mathrm{psi})$ to $31.2 \mathrm{kPa}$ (4.6 psi).

bPreload pressure is defined as the preload force divided by the bearing surface area $(\pi \times \mathrm{L} \times \mathrm{D})$ 

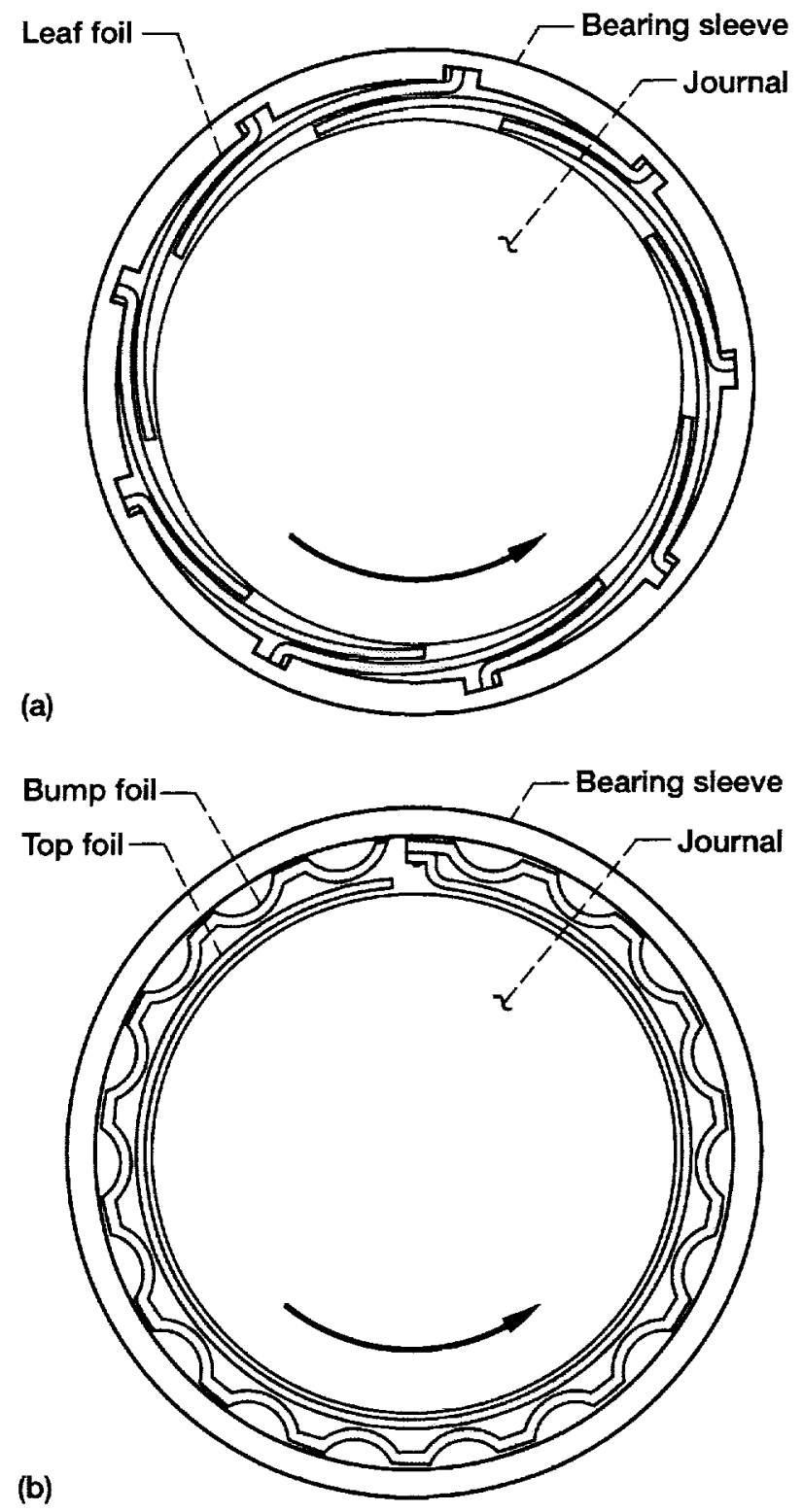

Figure 1.- Typical foil bearing test sleeves. (a) Leaftype foil bearing. (b) Bump-type foil bearing.
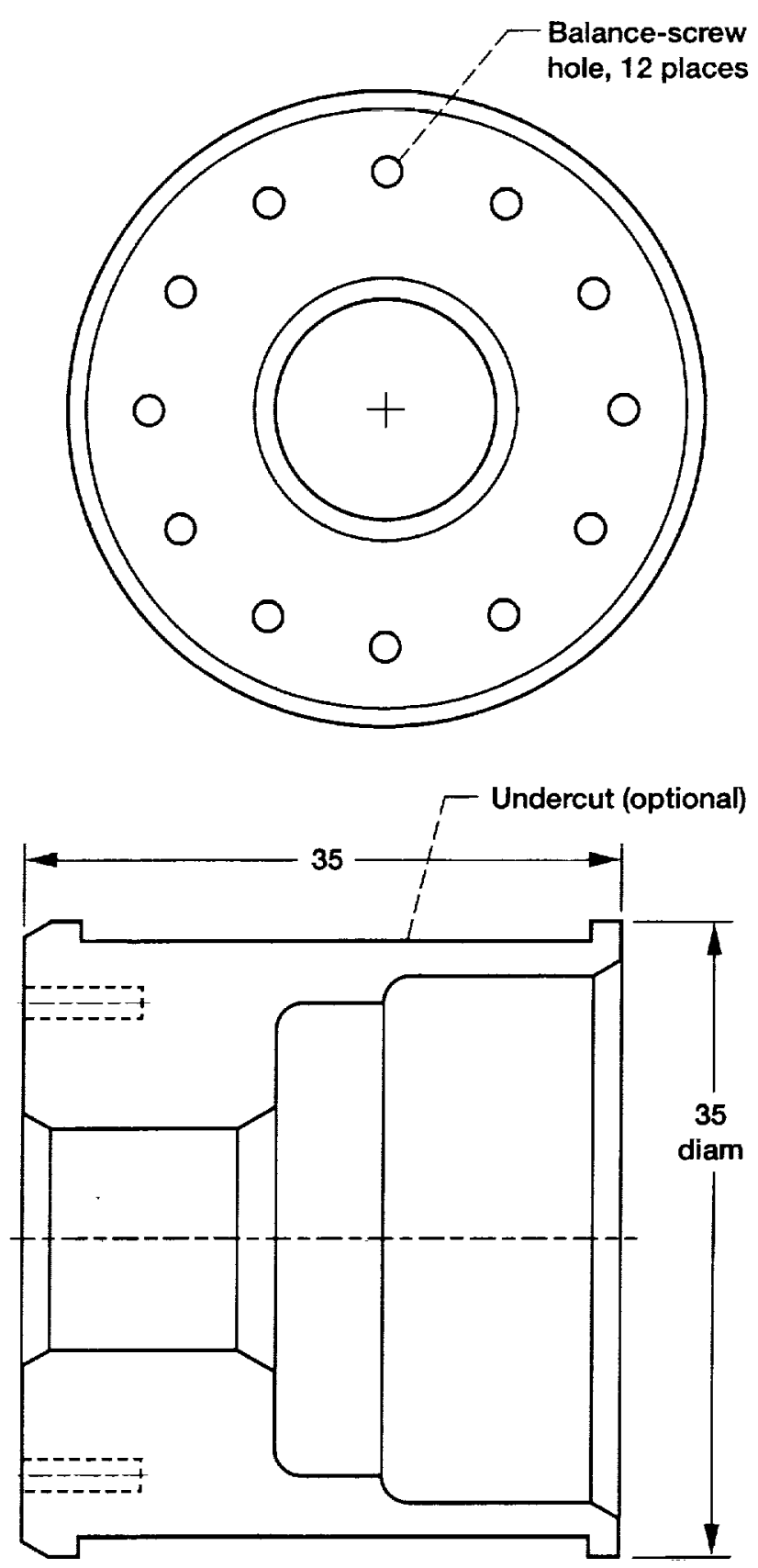

Figure 2.- Test journal. Note undercut on outside diameter of journal may be machined to accommodate a journal coating. Dimensions in $\mathrm{mm}$. 


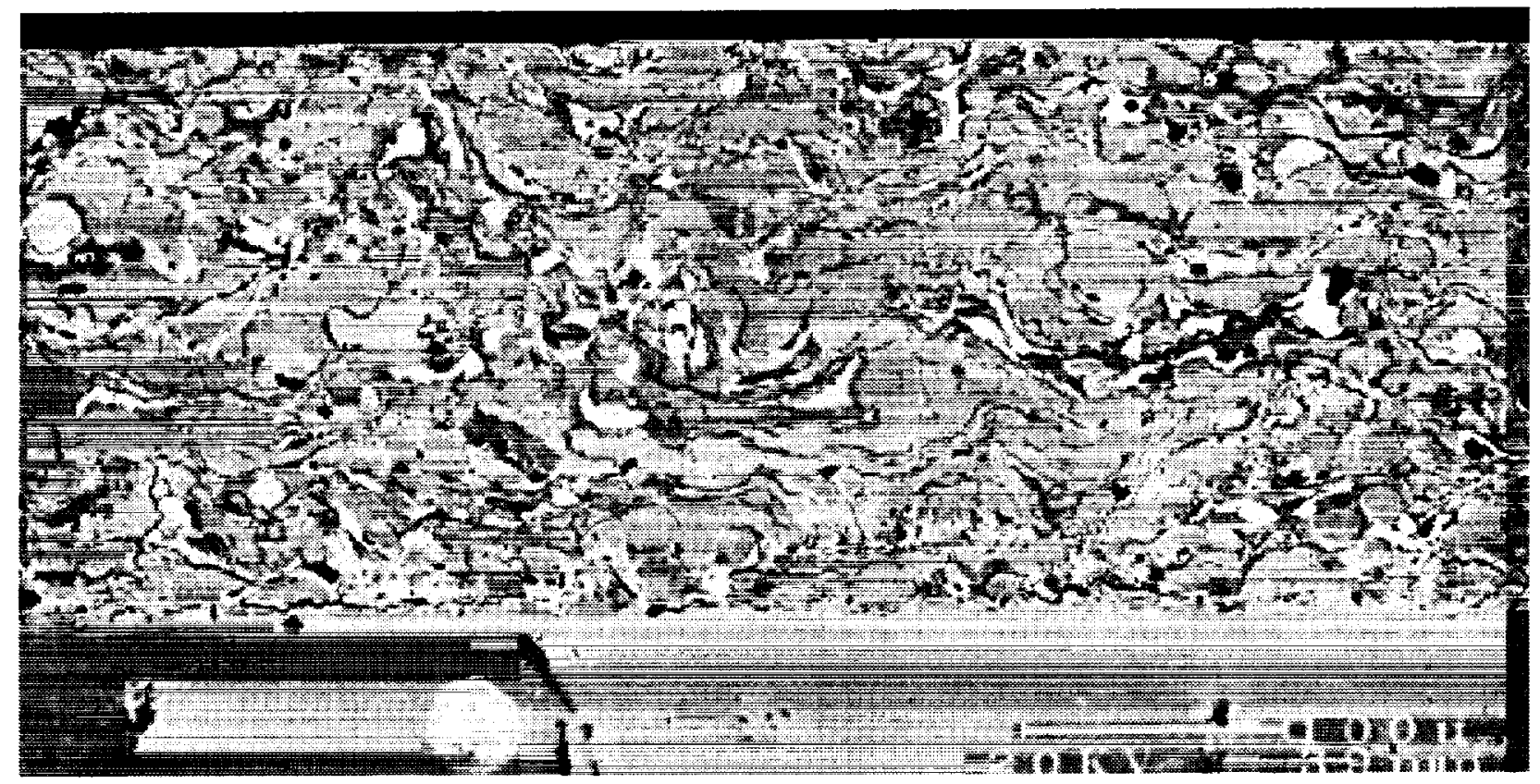

Figure 3.-Cross section SEM photomicrograph (backscattered) of PS 304. 


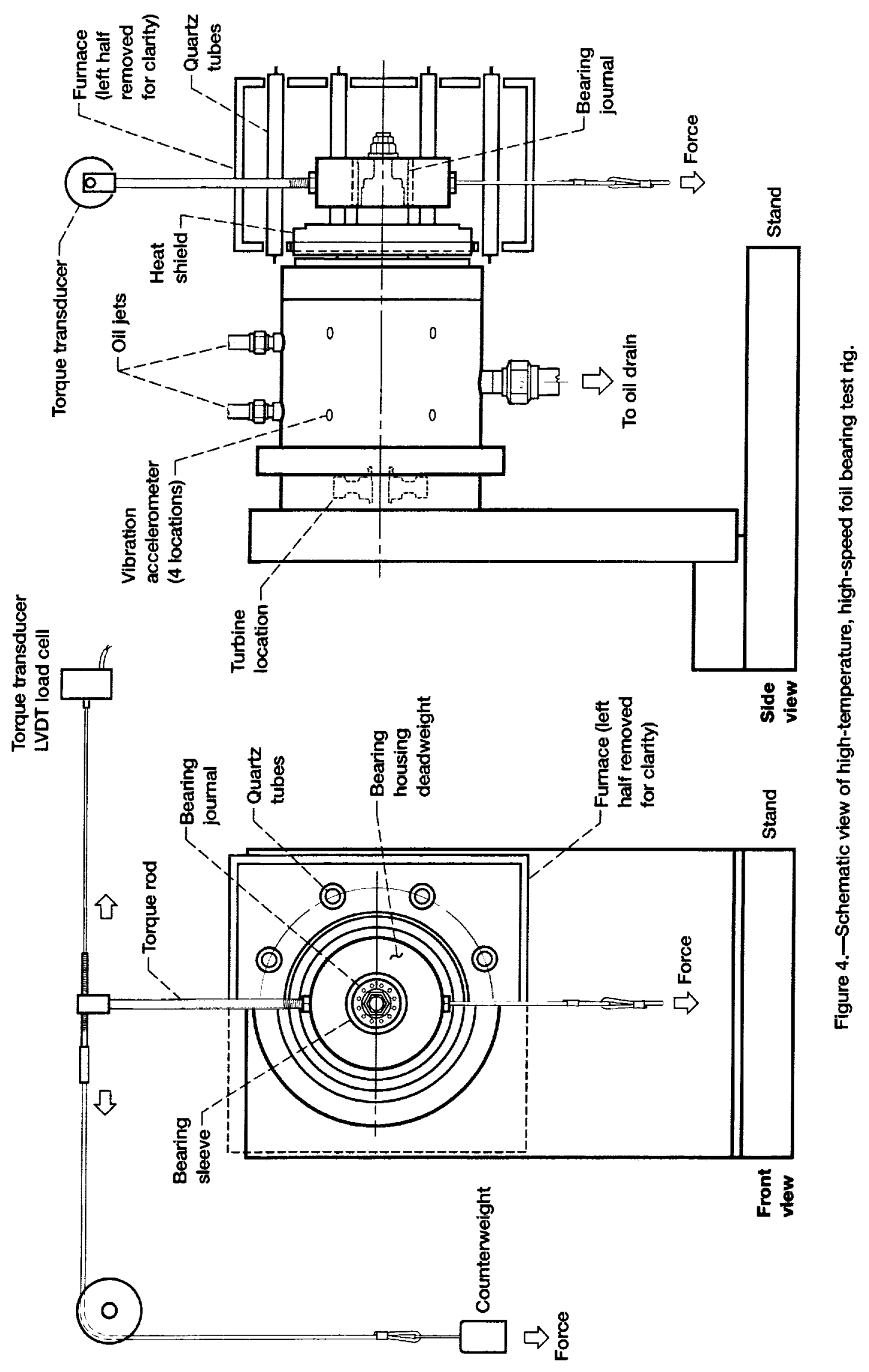




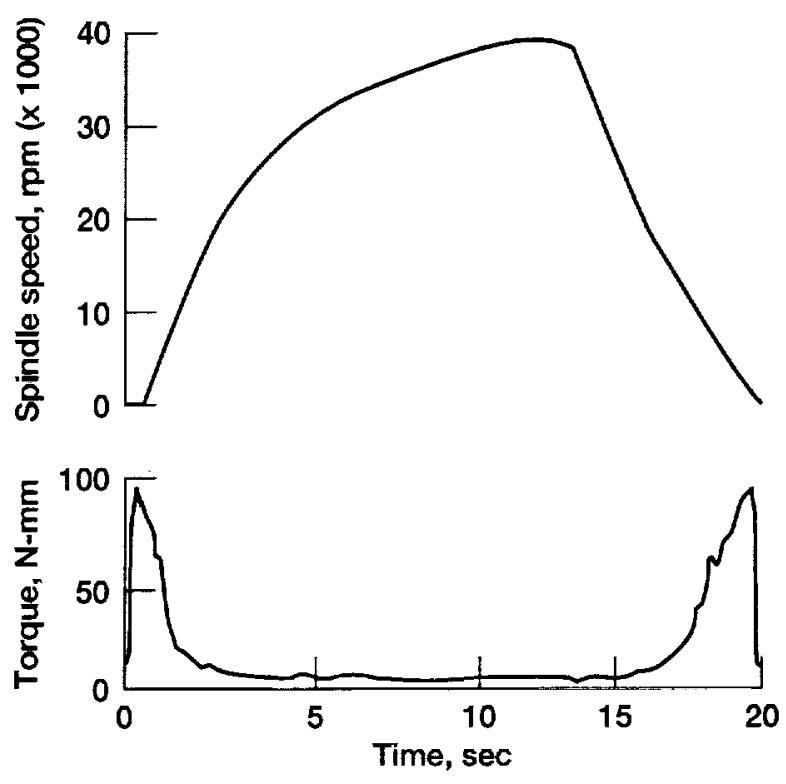

Figure 5.-Typical test cycle speed/torque trace.

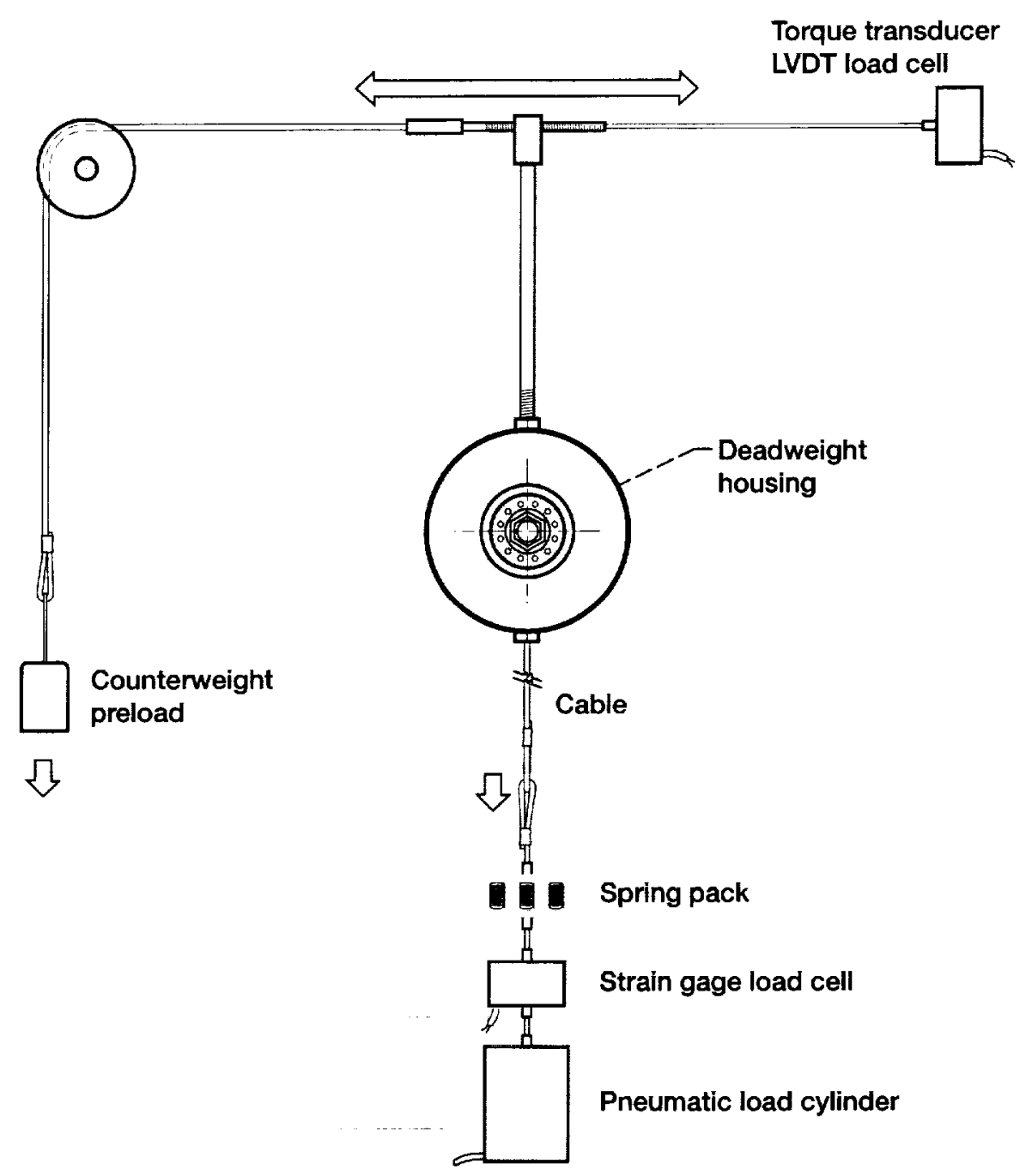

Figure 6.-Test rig partial front view showing torque and load measurement system. 


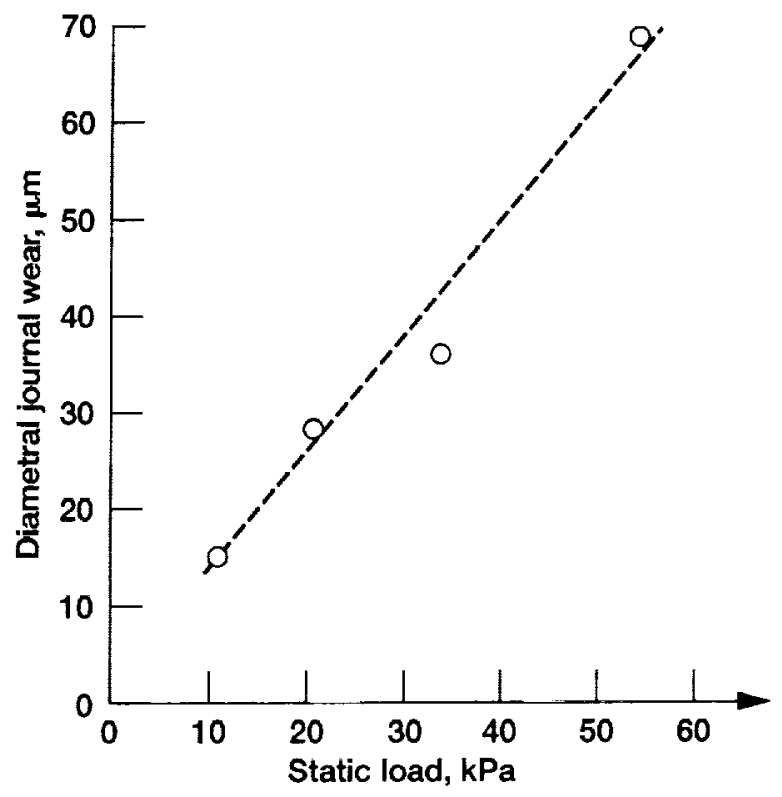

Figure 7.-Diametral journal wear versus static bearing load at $537^{\circ} \mathrm{C}$ after 30000 cycles.

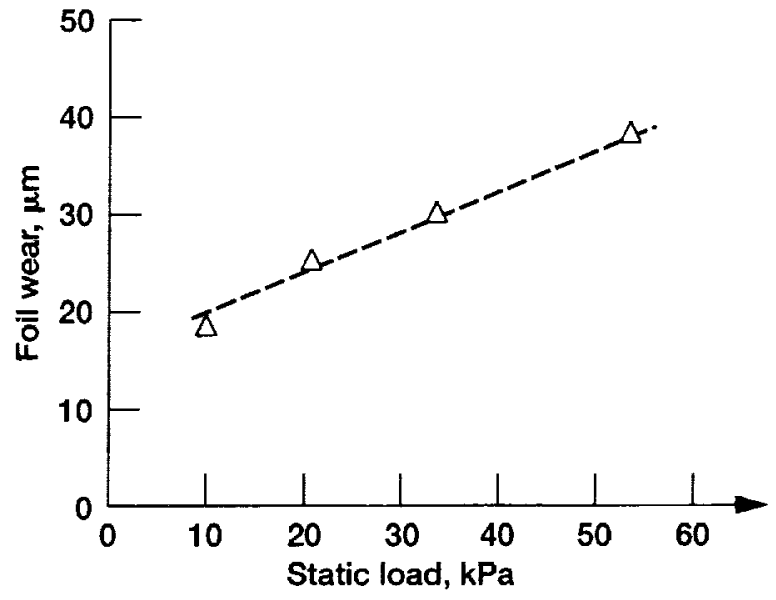

Figure 8.-Foil wear versus static bearing load at $537^{\circ} \mathrm{C}$ after 30000 cycles.

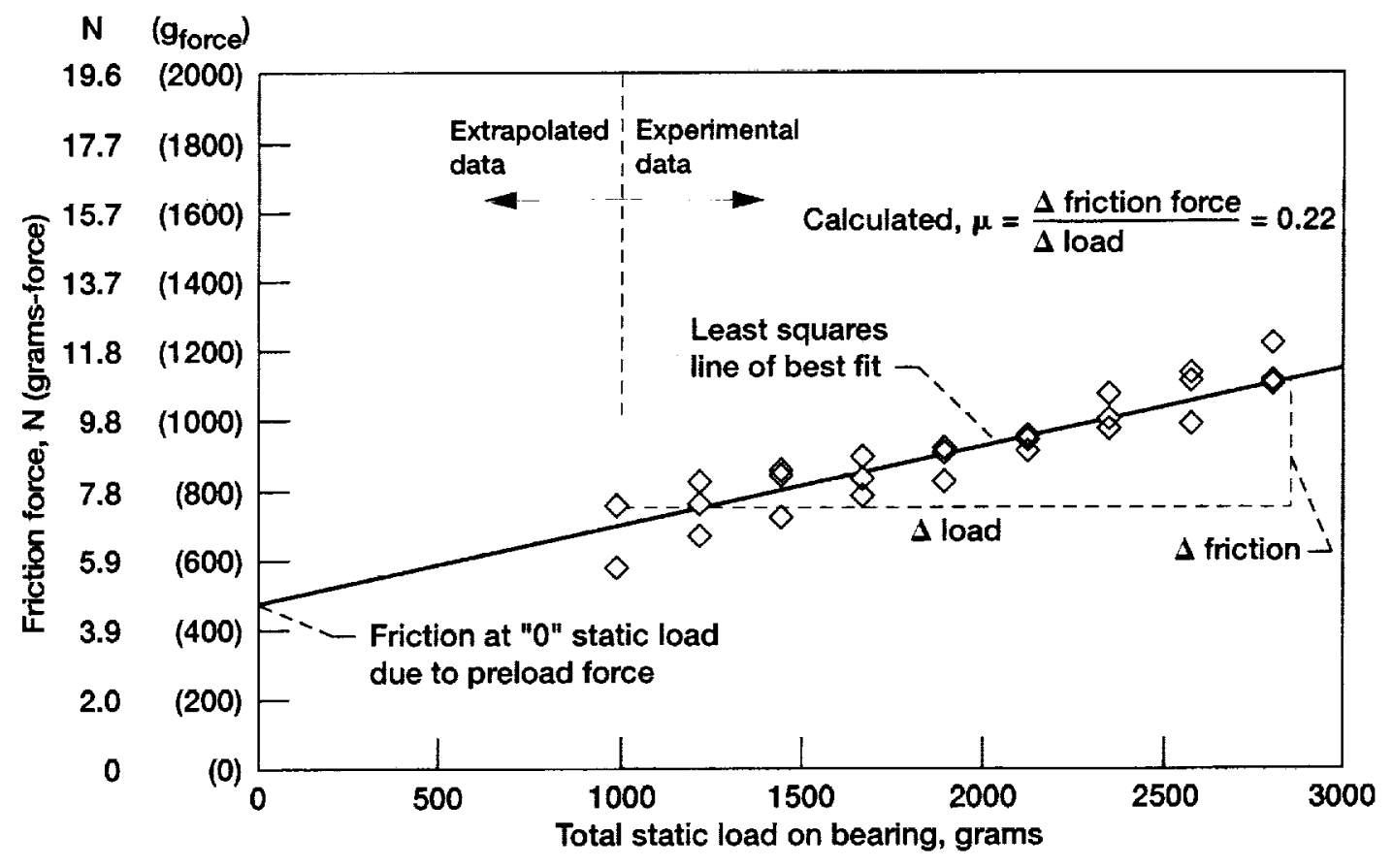

Figure 9.-Variation of measured bearing friction at $25^{\circ} \mathrm{C}$ as a function of total static load. Determination of calculated friction and preload force shown. 


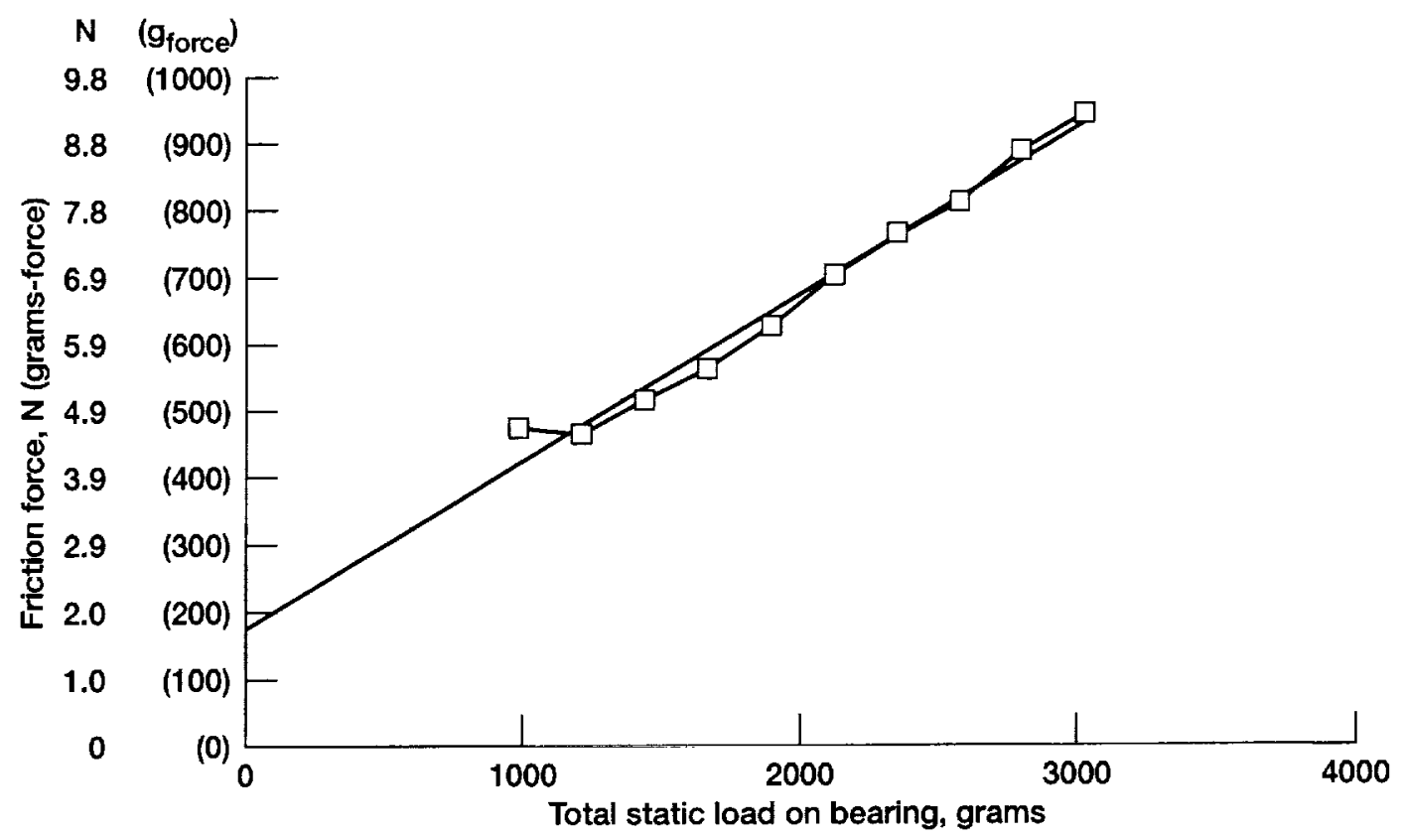

Figure 10.-Variation of measured bearing friction at $204^{\circ} \mathrm{C}$.

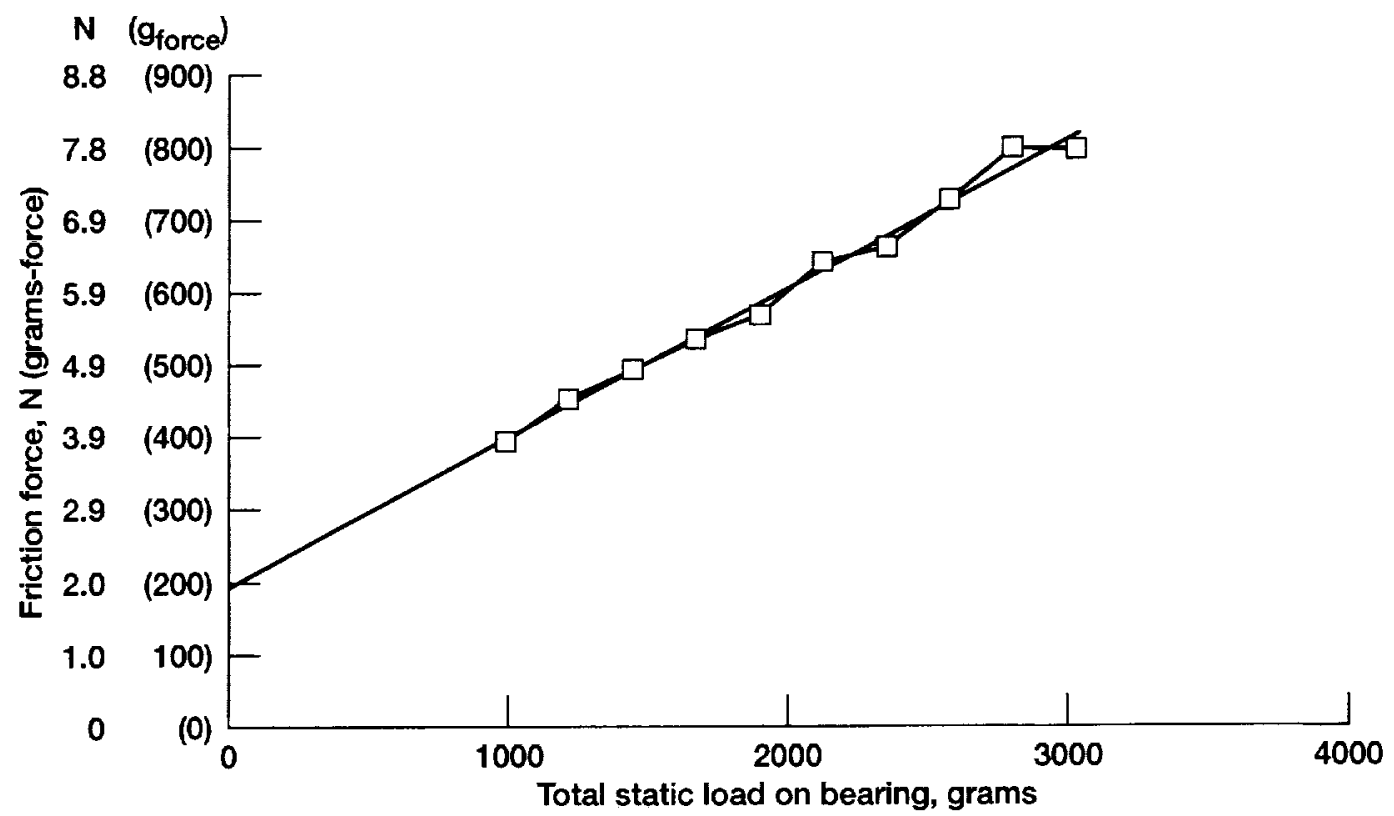

Figure 11.-Variation of measured bearing friction at $427^{\circ} \mathrm{C}$. 


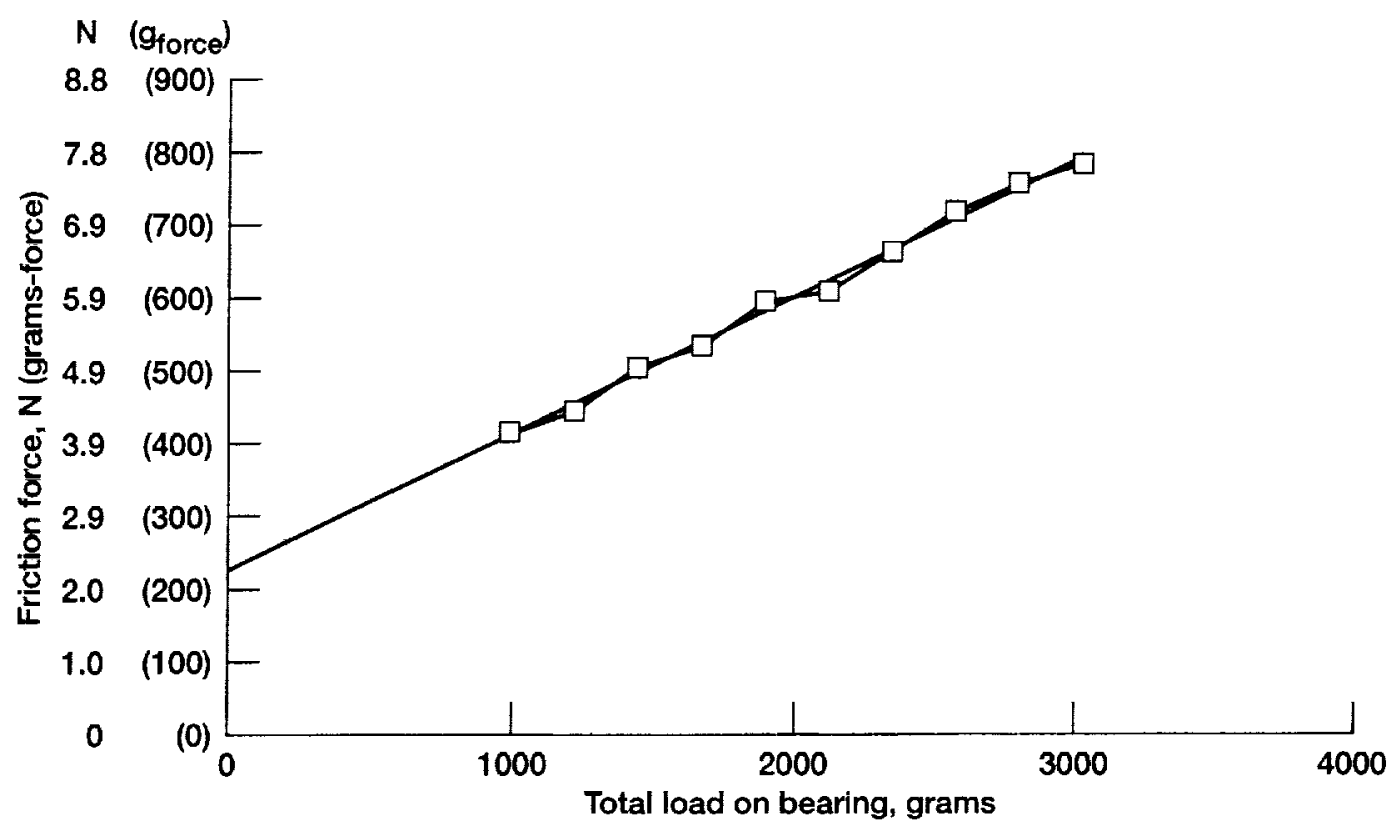

Figure 12.-Variation of measured bearing friction at $538^{\circ} \mathrm{C}$.

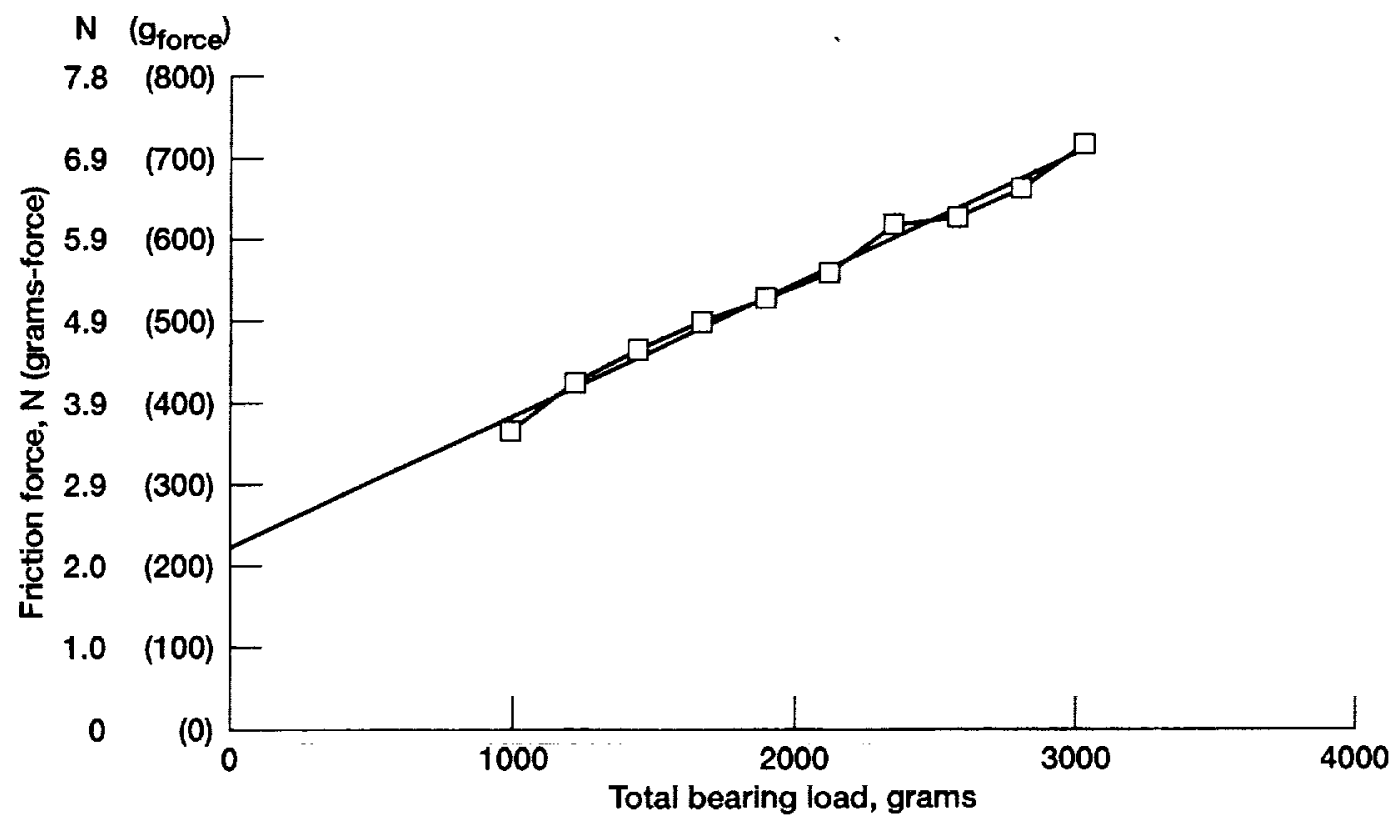

Figure 13.-Variation in measured bearing friction at $650^{\circ} \mathrm{C}$. 


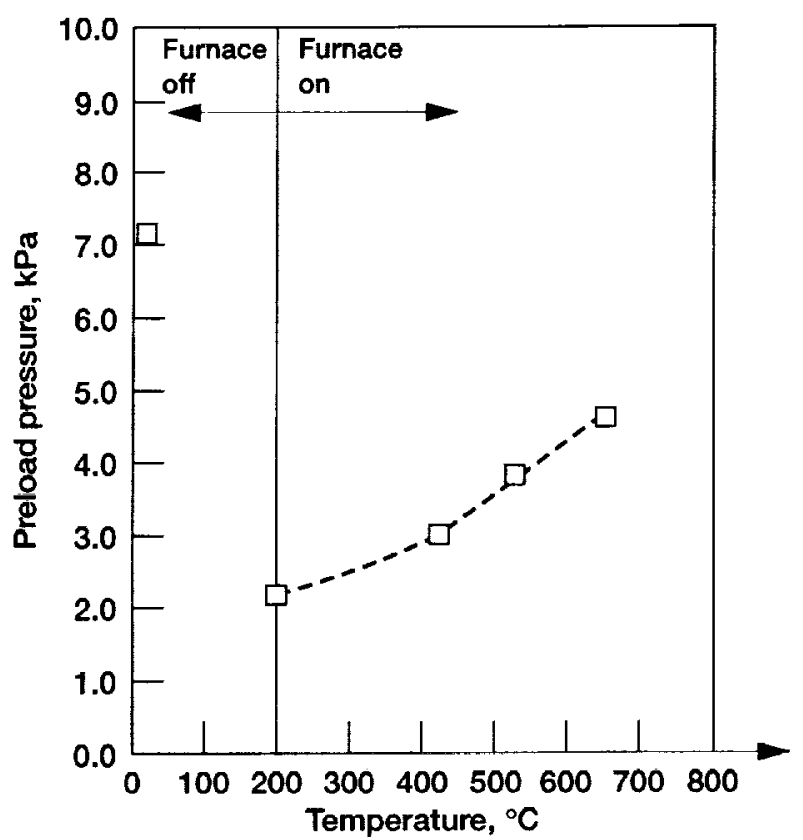

Figure 14.-The effects of bearing temperature on the calculated bearing preload pressure. 
Public reporting burden for this collection of information is estimated to average 1 hour per response, including the time for reviewing instructions, searching existing data sources, gathering and maintaining the data needed, and completing and reviewing the collection of information. Send comments regarding this burden estimate or any other aspect of this Davis Highway, Suite 1204, Arlington, VA 22202-4302, and to the Office of Management and Budget, Paperwork Reduction Project (0704-0188), Washington, DC 20503.
1. AGENCY USE ONLY (Leave blank)
2. REPORT DATE
March 2000
3. REPOAT TYPE AND DATES COVERED
Technical Memorandum

\section{TITLE AND SUBTITLE}

Performance and Durability of High Temperature Foil Air Bearings for

Oil-Free Turbomachinery

6. AUTHOR(S)

C. DellaCorte, V. Lukaszewicz, M.J. Valco, K.C. Radil, and H. Heshmat

7. PERFORMING ORGANIZATION NAME(S) AND ADDRESS(ES)

National Aeronautics and Space Administration

John H. Glenn Research Center at Lewis Field

Cleveland, Ohio 44135-3191
WU-523-18-13-00

\section{FUNDING NUMBERS}

9. SPONSORING/MONITORING AGENCY NAME(S) AND ADDRESS(ES)

National Aeronautics and Space Administration

Washington, DC 20546-0001
8. PERFORMING ORGANIZATION

REPORT NUMBER

E-11697-1

\section{SUPPLEMENTARY NOTES}

Prepared for the Annual Meeting sponsored by the Society of Tribologists and Lubrication Engineers, Nashville, Tennessee, May 7-11, 2000. C. DellaCorte, NASA Glenn Research Center; V. Lukaszewicz, Akima Corporation, Brook Park, Ohio 44142; M.J. Valco and K.C. Radil, U.S. Army Research Laboratory, NASA Glenn Research Center; H. Heshmat, Mohawk Innovative Technology, Inc., Albany, New York. Responsible person, C. DellaCorte, organization code 5140, (216) 433-6056.

Unclassified - Unlimited

Subject Categories: 07 and 27

Distribution: Standard

This publication is available from the NASA Center for AeroSpace Information, (301) 621-0390.

\section{ABSTRACT (Maximum 200 words)}

The performance and durability of advanced, high temperature foil air bearings are evaluated under a wide range $(10-50 \mathrm{kPa})$ of loads at temperatures from 25 to $650^{\circ} \mathrm{C}$. The bearings are made from uncoated nickel based superalloy foils. The foil surface experiences sliding contact with the shaft during initial start/stop operation. To reduce friction and wear, the solid lubricant coating, PS304, is applied to the shaft by plasma spraying. PS304 is a $\mathrm{NiCr}$ based $\mathrm{Cr}_{2} \mathrm{O}_{3}$ coating with silver and barium fluoride/calcium fluoride solid lubricant additions. The results show that the bearings provide lives well in excess of 30,000 cycles under all of the conditions tested. Several bearings exhibited lives in excess of 100,000 cycles. Wear is a linear function of the bearing load. The excellent performance measured in this study suggests that these bearings and the PS304 coating are well suited for advanced high temperature, oil-free turbomachinery applications.

\begin{tabular}{|c|c|}
\hline 14. SUBJECT TERMS \\
Lubrication; Turbomachinery; High temperature \\
\hline $\begin{array}{c}\text { 17. SECURITY CLASSIFICATION } \\
\text { OF REPORT }\end{array}$ & $\begin{array}{c}\text { 18. SECURITY CLASSIFICATION } \\
\text { OF THIS PAGE } \\
\text { Unclassified }\end{array}$ \\
Unclassified \\
\hline
\end{tabular}

NSN 7540-01-280-5500

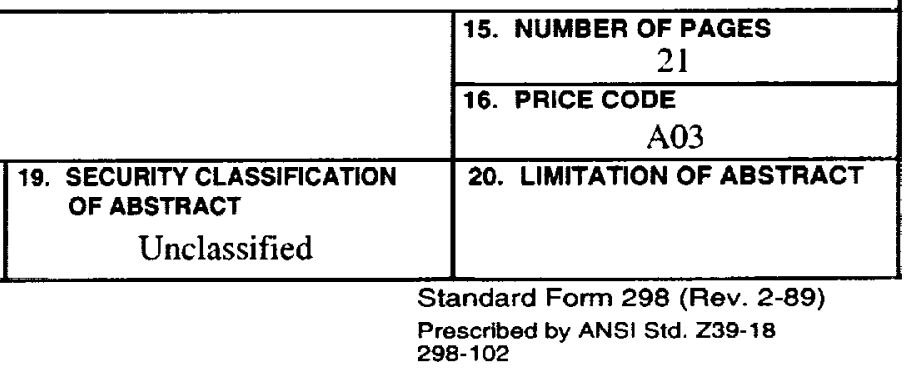


ERRATA

NASA/TM-2000-209187/REV1

Performance and Durability of High Temperature Foil Air Bearings for Oil-Free Turbomachinery

C. DellaCorte, V. Lukaszewicz, M.J. Valco, K.C. Radil and H. Heshmat

March 2000

On the report documentation page (Standard Form 298), block 10 should read

NASA/TM-2000-209187/REV1 
